Constituent Power from Cultural Practice : Implications from the Malheur Wildlife Refuge Occupation

\title{
Turpeinen, Juho
}

Edinburgh University Press

2020-10

Turpeinen , J 2020 , Constituent Power from Cultural Practice : Implications from the Malheur Wildlife Refuge Occupation . in M Arvidsson, L Brännström \& P Minkkinen (eds), Constituent Power : Law, Popular Rule and Politics . Edinburgh University Press , Edinburgh , pp. 114-131 . https://doi.org/10.3366/edinburgh/9781474454971.003.0008

http://hdl.handle.net/10138/321886

https://doi.org/10.3366/edinburgh/9781474454971.003.0008

acceptedVersion

Downloaded from Helda, University of Helsinki institutional repository.

This is an electronic reprint of the original article.

This reprint may differ from the original in pagination and typographic detail.

Please cite the original version. 


\title{
Constituent Power from Cultural Practice: Implications from the Malheur Wildlife Refuge Occupation
}

\author{
Juho Turpeinen
}

\section{Introduction}

I present here a defence of the people as the subject of constituent power, a case against ardently utopian thinking. ${ }^{1}$ The conjunctures in which bounded political entities are constituted are messy and problematic, but not hopeless or dystopian. This is to say, oppressive power relations are not always only oppressive, but should be viewed in context. The armed occupation of the Malheur National Wildlife Refuge, which took place in Oregon in 2016, makes for an illustrative case study of political identity formation, the foundation of a political regime rooted in popular rule. ${ }^{2}$ How are such identities, the discursively constructed subject positions of democracy, possible in the first place? What allows for them to be called democratic? What role does land play in this process?

Adopting the cultural studies ethos of studying not only meaning, but how meaning is produced, I approach the question of the people as the subject of constituent power by arguing for an interpretation of sovereignty as cultural practices of meaningmaking, as discursive struggles over cultural meaning that challenge and are challenged by relations of power. Sovereignty as cultural practice gives us a framework for understanding these processes of identity formation on three related and synchronous levels of politics. This approach should not be confused with 'cultural sovereignty', whether defined as a kind of bundle of intellectual property rights protective of indigenous cultures, 3 or as a normative political project that posits the right to define 'sovereignty' from within indigenous cultures, and in which tradition is to form the foundation of group identity and political action. 4 I do, however, share with this latter conceptualisation an effort to reconsider the relationships between law, politics, and culture. Indeed, to understand the workings of sovereignty in the abstract as well as in a specific temporal and spatial context, I employ the interdisciplinary approach of cultural studies, seeking the fecund interplay of theories from different traditions, and ultimately, the understanding a synthesis from therein may yield. As such, I aim to show that the conceptual frameworks of this collection relate to tangible political struggles.

\footnotetext{
${ }^{1}$ For an example of what I consider 'utopian', see the discussion on Jean-Luc Nancy and Jacques Rancière in Ari Hirvonen and Susanna Lindroos-Hovinheimo's chapter in this collection.

${ }^{2}$ As Wendy Brown puts it, 'Democracy detached from a bounded sovereign jurisdiction (whether virtual or literal) is politically meaningless: for the people to rule themselves, there must be an identifiable collective entity within which their power sharing is organized and upon which it is exercised'. Wendy Brown, 'We Are All Democrats Now...', in Giorgio Agamben, Alain Badiou, Daniel Bensaïd, Wendy Brown, Jean-Luc Nancy, Jacques Rancière, Kristin Ross, and Slavoj Žižek, Democracy in What State?, trans. William McCuaig (New York: Columbia University Press, 2011), p. 49. Compare with the argument for the necessity of 'the people' for democracy in Gill-Pedro's chapter in this collection.

3 Jason Zenor, 'Tribal (De)Termination: Commercial Speech, Native American Imagery and Cultural Sovereignty', Southwestern Law Review 48:1 (2019), pp. 81-104, at p. 83, note 13.

4 Wallace Coffey and Rebecca Tsosie, 'Rethinking the Tribal Sovereignty Doctrine: Cultural Sovereignty and the Collective Future of Indian Nations', Stanford Law \& Policy Review 12:2 (Spring 2001), pp. 191-222.
} 
I begin by grounding sovereignty, a contested and controversial concept, 5 in politics as a struggle over cultural meaning, as practices of meaning-making constitutive of a people. As these struggles bound meaning, they bound cultural entities, which constitute antagonistic groups that battle over cultural hegemony. This boundedness is not rigid, and especially in the case of the democratic subject, appears to be endangered, even fragile. I then considering sovereignty's relationship with land juxtaposing it with neoliberalism and anti-statism, which threaten to undo the people as a subject of constituent power, and thus popular rule. I complicate this reading by placing it in the context of postcolonial America. I conclude that sovereignty not only remains a powerful counterforce to neoliberal, anti-democratic projects, but that alliances with the state to construct the people as the subject of constituent power can serve this purpose. At the same time, the postcolonial context undermines these alliances as an emancipatory force.

\section{Sovereignty as constitutive meaning-making}

I ground sovereignty as cultural practice in the relationships between politics and culture. Politics constructs culture, just as politics, as a cultural product, is shaped by the culture in which it is produced. William Henry Sewell Jr. argues that the word 'culture' can be understood as two distinct concepts. Firstly, there is the analytical category of culture that is 'abstracted out from the complex reality of human existence' and designated as a field, sub-field or a method of study. 6 'Culture', in this sense, 'is neither a particular kind of practice nor practice that takes place in a particular social location. It is, rather, the semiotic dimension of human social practice in general'. 7 In the second meaning, 'culture' is understood to refer to one of many 'bounded world[s] of beliefs and practices', ${ }^{8}$ or simply as 'a way of life'. 9 I refer to 'culture' in both of these meanings, depending on the context: in the former sense, when I attempt to theorise how politics functions as a mechanism of constructing cultural meanings and vice versa; in the latter sense, when I focus on specific, bounded cultural meanings in the temporal and spatial context of the Malheur occupation. It is true, however, that in this latter meaning of the word as well, cultures are best conceptualised as 'partially coherent landscapes of meaning' whose 'boundedness is only relative and constantly shifting'. ${ }^{10}$ 'Culture' is, thus, inseparable from 'politics'; politics are the various struggles to, among other things, imbue social life with a degree of coherent if unstable and contested meaning.

\footnotetext{
5 Costas Douzinas, 'Athens Revolting: Three Meditations on Sovereignty and One on Its (Possible) Dismantlement', Law \& Critique 21:3 (2010), pp. 261-275, at p. 262. For an extended critique of the concept of sovereignty, see Michael Hardt and Antonio Negri, Assembly (New York: Oxford University Press, 2017).

${ }^{6}$ William H. Sewell, Jr., 'The Concept(s) of Culture', in Victoria E. Bonnell and Lynn Hunt (eds.), Beyond the Cultural Turn: New Directions in the Study of Society and Culture (Berkeley: University of California Press, 1999), pp. 35-61, at p. 39.

${ }_{7}$ Sewell, Jr., 'The Concept(s) of Culture', p. 48.

${ }^{8}$ Sewell, Jr., 'The Concept(s) of Culture', p. 39.

9 Neil Campbell and Alasdair Kean, American Cultural Studies: An Introduction to American Culture, third ed. (New York: Routledge, 2012), p. 6.

${ }^{10}$ Sewell, Jr., 'The Concept(s) of Culture', p. 58.
} 
Sewell points out that when dominant actors attempt to affect culture, they cannot do so merely by ordering cultural homogeneity, but more often resort to organising difference. ${ }^{11}$ Such a conception of culture is commensurate with an understanding of politics as a struggle over hegemony. ${ }^{12}$ Because this struggle relies on dominant (or hegemonic) practices that aim to produce meanings, and on the reactions to those practices from oppositional or marginalised groups, the struggle forms a 'dialectical dance' which 'far from demonstrating that cultures lack coherence, may paradoxically have the effect of simplifying and clarifying the cultural field'. ${ }^{13}$ This process, in which meaning is articulated and rearticulated, is the political struggle over culture. ${ }^{14}$

Crucially, understanding culture as 'a way of life', as one of many, implies a focus on the particular and the local. Even Sewell, who argues that we can no longer think of societies as separate from one another, with 'corresponding and well-integrated "culture[s]", 15 admits that "much cultural practice is concentrated in and around powerful institutional nodes including [...] most spectacularly, states' ${ }^{16}$ Although there are powerful dimensions of cultural practices that are global, giving reason to suspect whether Sewell's analysis is still relevant, much of social life can still be made intelligible through the concept of the nation-state. ${ }^{17}$ This is particularly true in the United States, where national identity remains a notable issue of interest, even as the coherence of any such concept has come under considerable criticism as both homogenizing and inward-looking. ${ }^{8}$ More broadly, the recent surge in popularity of ethno-nationalist movements in Europe and the United States serves as a testament to the enduring power of national identity. Furthermore, as Davina Cooper argues, 'recognizing the state-shaped character of social life makes it possible to explore the complex ways state and other (including grass-roots) governance logics and processes combine rather than assuming they meet as discrete independent forces'. ${ }^{19}$

To interpret the logics of this bounding of cultural identity and its relationship with democracy, I draw on Panu Minkkinen's division of theories of sovereignty into three categories: autocephalous, or sovereignty defined in legal terms as the power of the people or the authority of the state; heterocephalous, or political power that resists a single point in which sovereignty can be identified, marking a constellation of power relations; and acephalous, or sovereign self-knowledge that predates legal

\footnotetext{
${ }^{11}$ Sewell, Jr., 'The Concept(s) of Culture', p. 56.

${ }^{12}$ Indeed, Sewell is ambivalent about whether 'culture' in the second meaning is called 'culture' or 'hegemony'. Sewell, Jr., 'The Concept(s) of Culture', p. 58. For a post-Gramscian understanding of hegemony in political theory, see Ernesto Laclau and Chantal Mouffe, Hegemony and Socialist Strategy: Towards a Radical Democratic Politics, second ed. (London: Verso, 2014).

${ }_{13}$ Sewell, Jr., 'The Concept(s) of Culture', pp. 56-57.

${ }^{14}$ In other words, the 'transformational act of resignification - which is irreducibly discursive - is the generative source from which political rupture and social change is born'. Kobena Mercer,

'Introduction', in Stuart Hall, The Fateful Triangle: Race, Ethnicity, Nation, ed. Kobena Mercer (Cambridge: Harvard University Press, 2017), pp. 1-30, at p. 18.

${ }^{15}$ Sewell, Jr., 'The Concept(s) of Culture', p. 57.

${ }^{16}$ Sewell, Jr., 'The Concept(s) of Culture', pp. 55-56.

${ }_{17}$ Campbell and Kean, American Cultural Studies, p. 2.

${ }^{18}$ Campbell and Kean, American Cultural Studies, pp. 2-5.

19 Davina Cooper, 'Transformative State Publics', New Political Science 38:3 (2016), pp. 315-334, at p. 318.
} 
constitution. ${ }^{20}$ As this distinction makes clear, 'theories of sovereignty have been characterised by so many contortions and impasses that one could be justified in thinking that they are dealing with different phenomena'. ${ }^{21}$ Instead, I use these different 'heads' to refer to different levels of sovereignty that exist synchronously rather than as related groupings of theoretical approaches. Moreover, I understand autocephalous sovereignty to refer not only to constituent power in the juridical sense, but to entities of bounded cultural meaning. For Minkkinen:

the theory that posits a constitutionally ordered state already presupposes a subject that has reached full self-knowledge and that is also capable of 'knowing' the world that surrounds it. In that sense, the 'containing' that a constitutional framework provides is introduced by a sovereign subject, that is, the subject of knowledge and science. ${ }^{22}$

Building on this concept, I refer to acephalous knowledge not only in the context of producing the framework for a legal constitution, but in subjectivising a group of people as a political entity, a subject of constituent power, a player that can then act on the heterocephalous stage of politics. While cultural studies has recently approached law and legitimacy from the perspective of culture, ${ }^{23}$ my approach here is to look at how the concept of sovereignty, derived from legal theory, can be used to understand the processes of cultural identity formation that found the subjects of constituent power at the heart of democratic politics. ${ }^{24}$ In other words, I transpose the legal onto the cultural plane.

\section{Public lands, neoliberalism, and anti-statism}

I now turn to the case of the armed occupation of the Malheur National Wildlife Refuge to show how a cultural conceptualisation of sovereignty can help us understand the construction of bounded political entities that constitute popular rule. The occupation, which lasted 41 days in early 2016, saw Western ranchers, entrepreneurs, and other malcontents - predominantly white and male - journey to southeastern Oregon, and take over the remote wildlife refuge, owned by the federal government and managed by the United States Fish and Wildlife Service. The occupation had seemingly splintered off from a peaceful protest in the closest city, Burns, a small town of less than 3,000 people, against the impending federal imprisonment of two local ranchers, held 30 miles away. ${ }^{25}$ In the media, the occupiers' claims were largely communicated through brothers Ammon and Ryan

\footnotetext{
${ }^{20}$ Panu Minkkinen, Sovereignty, Knowledge, Law (New York: Routledge, 2009), pp. 8-9.

${ }^{21}$ Douzinas, 'Athens Revolting', p. 262.

${ }^{22}$ Minkkinen, Sovereignty, Knowledge, Law, p. 8.

${ }^{23}$ Jaafar Aksikas and Sean Johnson Andrews (eds.), Cultural Studies and the 'Juridical Turn': Culture, Law and Legitimacy in the Era of Neoliberal Capitalism (New York: Routledge, 2017).

24 This can be juxtaposed with institutional mediation-oriented (see Lukkari's chapter in this collection) and human rights-oriented (see Gill-Pedro's chapter in this collection) approaches to the question of constituent power.

${ }_{25}$ Carissa Wolf, Peter Holley, and Wesley Lowery, 'Armed men, led by Bundy brothers, take over federal building in rural Oregon', The Washington Post, 3 January 2016. Available at https://www.washingtonpost.com/news/post-nation/wp/2016/o1/o3/armed-militia-bundy-brotherstake-over-federal-building-in-rural-oregon/ (accessed 26 July 2019).
} 
Bundy, the apparent leaders of the occupation. ${ }^{26}$ The occupiers claimed that the federal government had no right to the land and that their attempt to seize the land was for the economic well-being of ranchers and private citizens. ${ }^{27}$ The occupation was widely condemned by legal experts, politicians, and commentators in mainstream and social media. ${ }^{28}$ It ended with all occupiers arrested, save for one who was shot to death by Oregon State Patrol. While the majority of the accused pleaded guilty, many of the key figures of the occupation, including Ammon and Ryan Bundy, were later acquitted of conspiracy charges. ${ }^{29}$

While scholars from different fields have taken interest in the values that the occupiers represent, values that may resonate with a much broader audience, 30 the media at the time focused on the sensational character of the militia-esque occupiers, giving them the opportunity to articulate their anti-statist rhetoric. Although their messaging was at times ambiguous, ${ }^{31}$ their anti-statism is what links the armed occupation to neoliberalism. As Carolyn Gallaher puts it, "the occupier's stated goal to seize public land and "give it back" to ranchers - is inconsistent with neoliberal

\footnotetext{
${ }^{26}$ See e.g. Ralph Ellis, Holly Yan, and Sara Sidner, 'Oregon protest leader: "There is a time to go home", CNN, 7 January 2016. Available at https://edition.cnn.com/2016/o1/o6/us/oregon-wildliferefuge-armed-protest/ (accessed 29 July 2019); John Sepulvado, Oregon Public Broadcasting, 'Ryan Bundy: We'll leave if community want us to', Public Broadcasting Service, 5 January 2016. Available at https://www.pbs.org/newshour/nation/ryan-bundy-well-leave-if-community-wants-us-to (accessed 29 July 2019).
}

${ }^{27}$ Les Zaitz 'Oregon militant leader Ammon Bundy exudes calm as he presides over occupation', The Oregonian, 3 January 2016. Available at https://www.oregonlive.com/pacific-northwestnews/2016/01/ammon_bundy_exudes_calm_as_he.html (accessed 29 July 2019).

${ }^{28}$ See e.g. Erwin Chemerinsky, 'Private: No Legal Issue in Oregon', American Constitution Society (blog), 7 January 2016. Available at https://www.acslaw.org/expertforum/no-legal-issue-in-oregon/ (accessed 29 July 2019); Dana Ford, 'Oregon governor tells armed protesters to leave', CNN, 8 January 2016. Available at https://edition.cnn.com/2016/01/o7/us/oregon-wildlife-refuge-armed-protest/ (accessed 29 July 2019); Josh Zeitz, 'Sorry, Ranchers, You're Actually Big-Time Government Moochers. What Ammon Bundy doesn't get about U.S. history', Politico, 7 January 2016. Available at https://www.politico.com/magazine/story/2016/o1/bundhy-protest-ranchers-actually-governmentmoochers-213510 (accessed 29 July 2019); Wilfred Chan, 'Oregon Standoff? Call it a "Y'all Qaeda" attack, say Internet users', CNN, 4 January 2016. Available at https://edition.cnn.com/2016/01/04/us/oregon-standoff-social-media-reaction/ (accessed 29 July 2019).

${ }^{29}$ Courtney Sherwood and Kirk Johnson, 'Bundy Brothers Acquitted in Takeover of Oregon Wildlife Refuge', The New York Times, 27 October 2016 Available at https://www.nytimes.com/2016/10/28/us/bundy-brothers-acquitted-in-takeover-of-oregon-wildliferefuge.html (accessed 29 July 2019).

${ }^{30}$ See for example Carolyn Gallaher, 'Placing the Militia Occupation of the Malheur National Wildlife Refuge in Harney County, Oregon', ACME: An International E-Journal for Critical Geographies 15:2 (2016), pp. 293-308, available at https://www.acmejournal.org/index.php/acme/article/view/1312/1173 (accessed 24 July 2019); Michael C. Blumm and Olivier Jamin, 'The Property Clause and Its Discontents: Lessons from the Malheur Occupation', Ecology Law Quarterly 43:4 (2016), pp. 781-826. From the perspective of sovereignty, Courtney Irons has discussed patriarchy and masculinity in the occupiers' rhetoric. Courtney Irons, 'The Patriarch and the Sovereign: The Malheur Occupations and the Hyper-Masculine Drive for Control', Columbia Journal of Law and Social Problems 51:3 (2018), pp. 479-522.

${ }^{31}$ See for example Ashley Fantz, Joe Sutton and Holly Yan, 'Armed group's leader in federal building: "We will be here as long as it takes", $C N N$, 4 January 2016. Available at https://edition.cnn.com/2016/01/o3/us/oregon-wildlife-refuge-protest/index.html (accessed 29 July 2019). 
goals but ultimately dovetails with its solutions'. ${ }^{2}$ After all, in the United States, neoliberalism manifests in the context of 'long-established antistatism and new managerialism'.33 Greg Walden, the U.S. Representative for Oregon's 2nd congressional district, reiterated the relevance of anti-statism to contemporary Republican politics by agreeing with the aims albeit not the means of the armed occupiers. 34

The anti-statist occupiers construct a rhetorical group identity that closely resembles the 'sovereign citizen' movement, which holds the federal government to be largely illegitimate. 35 In this heterodox interpretation, the federal government has extremely narrow powers that can almost never be expanded upon; actions usually considered to be well within the legal powers of the federal government are seen by militia groups as illegitimate if they encroach on 'the freedoms of particular - usually white and male - citizens'. ${ }^{6}$ Such an interpretation relies on historically derived notions of racial hierarchy and antagonism towards the federal government. 37 In a 'sovereign citizen' interpretation, any autocephalous justification of the federal government's power is severely questioned. The government is largely viewed as an oppressive political power in the heterocephalous realm. Ammon and Ryan Bundy's father, Cliven Bundy, had previously tried to use such a failed defence in court in relation to his land dispute in Nevada. ${ }^{8}$ Following in his father's footsteps, '[Ammon] Bundy used the occupation to repeatedly declare federal land ownership unconstitutional, and BLM powerless to manage federal lands'.39

The occupiers' anti-statism can also be read in the context of the Sagebrush Rebellion, a movement that right-wing politicians tapped into in the 1970 s and 1980s.40 Although some states are exceptions, the current trend for the federal government is, and has been for decades, to diminish rather than increase the amount of federal lands. This has been the case in the 11 contiguous western states as well. However, the Sagebrush rebels' call to simply transfer federal lands to the states has been unsuccessful. ${ }^{41}$ Critics have long held that the argument that federal lands

\footnotetext{
${ }^{32}$ Gallaher, 'Placing the Militia Occupation', p. 298.

33 Wendy Brown, Undoing the Demos (New York: Zone Books, 2015), p. 20.

34 Mike DeBonis, 'Oregon congressman: Those occupiers kind of have a point', The Washington Post, 6 January 2016. Available at https://www.washingtonpost.com/news/powerpost/wp/2016/o1/o6/oregon-congressman-thoseoccupiers-kind-of-have-a-point/?noredirect=on\&utm_term=.1866oecdcb11 (accessed 29 July 2019).
}

35 Lane Crothers, Rage on the Right: The American Militia Movement from Ruby Ridge to Homeland Security (Lanham: Rowman \& Littlefield, 2003), pp. 58-61.

${ }^{36}$ Crothers, Rage on the Right, p. 58, pp. 58-61.

37 Crothers, Rage on the Right, p. 60. Although, as Crothers notes, militias do not necessarily see themselves as racist, but defend their views as constitutional. Crothers, Rage on the Right, p. 73.

${ }^{38}$ Blumm and Jamin, 'The Property Clause', pp. 788-789.

39 Blumm and Jamin, 'The Property Clause', p. 793.

$4^{\circ}$ Richard White, 'It's Your Misfortune and None of My Own': A New History of the American West (Norman: University of Oklahoma Press, 1991), pp. 567-568.

${ }^{41}$ Carol Hardy Vincent, Laura A. Hanson, and Carla N. Argueta, 'Federal Land Ownership: Overview and Data', U.S. Congressional Research Service, R42346, 3 March 2017. Accessed at Federation of American Scientists, https://fas.org/sgp/crs/misc/R42346.pdf (accessed 29 July 2019), pp. 15-20. 
should be transferred to the states is not much more than a ruse under which public lands would be privatised. ${ }^{2}$

Seemingly at the intersection of these traditions, the militant, armed occupiers that took control of the facilities at the refuge, claimed they were doing so to help the people and the community. 43 The 'economics' that the occupiers talked about could supposedly only be achieved through local or private means. 44 According to a County Commissioner, however, Harney County would not be able to afford managing what are currently federal lands. 45

For Bonnie Honig, such privatisation of public things would lead to an undoing of popular rule through an erosion of the foundations of a democratically-oriented people. $4^{6}$ Honig connects sovereignty to public things, comparing public things to a blanket or toy, through the use of which an infant learns to think of 'itself as a unit as well', but transposes this object-relations concept from personality in developmental psychology to collectivity in political theory.47 In the political realm, this could mean that transitional objects help individuals move towards thinking about the world beyond themselves, towards a democratic imagination. ${ }^{48}$ For Honig, such objects are public. While private things may have a 'magic' of their own, they lack the political magic of public things. Honig concedes that we cannot know whether private things can or cannot serve this function, but that the fetishist obsession with the same privately owned things (such as iPhones) appears to be 'more like the ruin' that reminds us of our need for public things in neoliberal times. 49

Although Honig argues for 'a democratic politics based not on identity and inclusion',50 public things bound cultural meaning through acephalous knowledge. They 'press us into relations with others', 51 and have the potential to 'constitute citizens equally as citizens'.52 Public things equalise privilege inherent to wealth and various social intersections, such as gender, race, and ethnicity, while private things cannot equalise privilege - after all, they are not available to all. It follows that, if

\footnotetext{
${ }^{42}$ White, It's Your Misfortune, pp. 567-568.

43 The Oregonian, 'Militant leader explains intentions on Oregon refuge takeover', YouTube, 3 January 2016. Available at https://www.youtube.com/watch?v=eb8Oq83Uzbo (accessed 29 July 2019); Sepulvado, 'Ryan Bundy'.

${ }_{44}$ Zaitz, 'Oregon militant leader'; Oregonian, 'Militant leader explains intentions'.

${ }^{45}$ Samantha White, 'County Court Continues Conversation Concerning Refuge Occupation', Burns Times-Herald, 27 January 2016. Available at http://btimesherald.com/2016/o1/27/county-courtcontinues-conversation-concerning-refuge-occupation/ (accessed 29 July 2019).

${ }^{46}$ Bonnie Honig, Public Things: Democracy in Disrepair (New York: Fordham University Press, 2017).

47 Honig, Public Things, pp. 16-17.

${ }^{48}$ Honig, Public Things, p. 17.

49 Honig, Public Things, pp. 30-31.

${ }^{5}$ Felicity Collins, 'Disturbing the Peace: The Ghost in Bedevil and The Darkside', Critical Arts 31:5 (2017), pp. 107-114, at p. 110.

${ }^{51}$ Honig, Public Things, p. 6.

${ }^{2}$ Honig, Public Things, p. 11. Public things also 'provide a basis around which to [...] reimagine various modes of collective being together in a democracy'. Honig, Public Things, p. 24
} 
public things are a necessary condition of democracy, then all efforts to wrest land from public control are inherently anti-democratic. Privatisation of public lands, either directly or because the county or state could not afford to manage the lands, 53 threatens the democratically subjectivising knowledge of public lands. What is at stake is not just the loss of the political power of the people in the heterocephalous sense, but the people in which autocephalous sovereignty is grounded, due to a loss of acephalous sovereign knowledge, undoing constituent power. As Jason Frank puts it, what Honig 'diagnoses is the disappearance of the political itself [...] the capacity of ordinary people to respond collectively to challenges they commonly face'.54

The 2016 occupation was not, of course, the first time Euro-Americans laid claim to the ancestral lands of the Northern Paiutes. Seemingly reflecting on this past, Ryan Bundy reportedly claimed that the occupiers 'recognize that the Native Americans had the claim to the land, but they lost that claim [...] There are things to learn from cultures of the past, but the current culture is the most important'.55 Despite the occupiers' later rhetoric that they welcomed the Burns Paiute Tribe to discuss the federal treatment of Paiute artefacts with them (an invitation the tribe refused), ${ }^{6}$ any attempt at allegiance was undermined by the general implications of an armed, exclusive occupation that aimed at the privatisation of a public thing. Instead of building alliances, the white male occupiers' 'assembly' radically excluded others. Due to the armed nature of the occupation, the Malheur protesters were attacking the right to public land, the right of the Burns Paiute Tribe to have the federal government manage the land, and the right of locals - who, subsequently, assembled at other public sites57 - to protest against the occupiers' presence.

In cases where students have seized university buildings, Judith Butler argues, they have claimed them for public education, to wrest them from neoliberalism. $5^{8}$ The Malheur occupiers, on the other hand, claimed public land for privatisation. Yet, does this act not signify the precarity of the occupiers, and demand that that precarity be redressed, even if it cannot be redressed by the means they propose? Is it not liveable

\footnotetext{
53 Gallaher, 'Placing the Militia Occupation', p. 304.

54 Jason Frank, 'Collective Actors, Common Desires', Political Research Quarterly, 68:3 (2015), pp. 637-641, at p. 637. In Honig's words: 'Without public things, we have nothing or not much to deliberate about, constellate around, or agonistically contest'. Honig, Public Things, p. 5 .

55 Rebecca Boone, Associated Press, ‘4,00o artifacts stored at Oregon refuge held by armed group', Business Insider, 15 January 2016. Available at https://www.businessinsider.com/ap-40oo-artifactsstored-at-oregon-refuge-held-by-armed-group-2016-1?r=US\&IR=T\&IR=T (accessed 29 July 2019).

${ }^{5}$ Sam Levin, 'Fresh outrage after militia seen rifling through tribal artifacts at Oregon refuge', The Guardian, 21 January 2016. Available at https://www.theguardian.com/us-

news/2016/jan/21/oregon-militia-standoff-malheur-wildlife-refuge-native-american-artifacts-paiutetribe (accessed 29 July 2019); LaVoy Finicum 'Jan 20 Native American Artifacts', YouTube, 21 January 2016. Available at https://www.youtube.com/watch?v=EzFhWAcuzio (accessed 29 July 2019).
}

${ }_{57}$ Conrad Wilson and Ryan Haas, Oregon Public Broadcasting, 'Oregon residents in packed town hall want armed militia to leave', Public Broadcasting Service, 7 January 2016. Available at https://www.pbs.org/newshour/nation/oregon-residents-in-packed-town-hall-want-armed-militiato-leave (accessed 29 July 2019).

$5^{8}$ Judith Butler, Notes Toward a Performative Theory of Assembly (Cambridge: Harvard University Press, 2015), pp. 94-95. 
life that the Malheur occupiers demand? Is their precarity not, thus, related to protests against the very neoliberal ideals they implicitly support?59

\section{Claiming sovereignty in the post-colonial context}

Conversely, the Burns Paiute Tribe, the ancestors of whom were the original habitants of the area, articulated a different kind of relationship with land, sovereignty, and the federal government. Charlotte Rodrique, the Burns Paiute Tribal Chair at the time, made an attempt to retain a distinction between cooperation with the government and a ceded heterocephalous sovereignty, to maintain a political and not just cultural distinction in relation to the United States. The Burns Paiute Tribe was adamant when talking to the press that it had not in fact given away its land; by signing the treaties in 1868, the Paiutes only entrusted the federal government to be the land's guardian. ${ }^{60}$ In The Oregonian, Rodrique is quoted saying that the tribe has a 'good working relationship' with the federally owned and managed refuge, and hold the federal government to be 'a protector of [their] cultural rights in that area'. ${ }^{61}$ At the same time, Rodrique maintains that 'we as a tribe view that this is still our land no matter who's living on it'. ${ }^{62}$ This claim should be considered in the context of the juridical status of Native Americans in the United States. Although rulings of the Supreme Court have been interpreted to afford Native American tribes varying degrees of sovereignty, 63 Congress retains plenary powers over Indian affairs, and whether and to what degree Native American treaties and rights are upheld. Courts tend to defer to this power 'when it is to the detriment of tribes, while asserting judicial review over congressional acts that benefit tribes' ${ }^{64}$

In practical terms, then, it makes sense for the Burns Paiute Tribe to maintain a relationship with the federal government. Working towards heterocephalous power and autocephalous sovereignty without antagonising the federal government would seem to require a deft hand. Parallels can be drawn between the events of 2016 and the character of Sarah Winnemucca, a controversial $19^{\text {th }}$ century figure. 65 Like Rodrique in 2016, Winnemucca appeared 'to imagine a form of incorporation that does not require dissolution of Northern Paiute sovereignty, a form the United States is reluctant to acknowledge'. 66

After federal war efforts against the Paiutes brutally concluded, a treaty between the parties created the Malheur Indian Reservation in 1872, on the Paiutes' ancestral

\footnotetext{
59 Cf. Butler, Notes, pp. 126-127.

${ }^{60}$ E.g. Ian K. Kullgren, 'Burns Paiute Tribe: Militants need to get off "our land”, The Oregonian, 6 January 2016. Available at https://www.oregonlive.com/pacific-northwestnews/2016/o1/burns_piaute_tribe_militants_s.html (accessed 26 July 2019).

61 Kullgren, 'Burns Paiute Tribe'.

62 Kullgren, 'Burns Paiute Tribe’.

63 Federico Lenzerini, 'Sovereignty Revisited: International Law and Parallel Sovereignty of Indigenous Peoples', Texas International Law Journal 42:1 (2006), pp. 155-189, at pp. 165-169.
}

${ }_{4}$ Michalyn Steele, 'Plenary Powers, Political Questions, and Sovereignty in Indian Affairs', UCLA Law Review 63:3 (2016), pp. 666-710, at p. 671. See also pp. 669-671.

${ }_{65}$ Cari M. Carpenter, 'Sarah Winnemucca Goes to Washington: Rhetoric and Resistance in the Capital City', American Indian Quarterly 40:2 (Spring 2016), pp. 87-108, at pp. 97-98.

${ }^{66}$ Carpenter, 'Sarah Winnemucca', p. 96. 
lands. ${ }^{67}$ Experiences and interpretations vary on what the Malheur Indian Reservation actually was. Winnemucca described the (by then abolished) reservation as the 'Paiutes' home'. ${ }^{68}$ Conversely, historian Nancy Langston argues that the reservation was 'intended to free up land for ranching' and soon 'became a site of constraint and anger for the Paiute' when ranchers and Indian agents tried to force the Paiutes out of their nomadic ways and into farming. ${ }^{69}$ Regardless, ranchers and settlers soon began to take over the lands of the reservation, leading to a Paiute uprising that was quickly crushed. ${ }^{70}$ In 1879 , the Malheur Paiutes were forcibly moved to another reservation in 'a 350-mile journey that took a number of lives'.71 Ranchers then fully took over the Malheur Indian Reservation, which was finally abolished in 1889 , returning the land to the public domain. ${ }^{72}$ During the early $20^{\text {th }}$ century, the environmental devastation wrought by agricultural developments, not just in Malheur but across the United States, sparked interest in conservation efforts. President Theodore Roosevelt established the Malheur Lake Bird Reservation in 1908,73 and in 1934, when the cattle empire was in ruins, the rest of the area was obtained by the federal wildlife refuge system. 74

Winnemucca struggled to restore the Malheur Reservation to the Paiutes, but the area remained largely public land and eventually became the wildlife refuge. Cari M. Carpenter argues that regardless of their ostensible failure, Winnemucca's attempts represent resistance. They represent a performance of heterocephalous power in a time when federal policy was shifting away from treating Native American tribes as external nations and towards 'inward surveillance and manipulation'.75 The tension between struggles for political distinction and for cultural distinction within political assimilation continues to this day. ${ }^{76}$ The latter, what Carpenter refers to as 'multiculturalism', is a way of conceptualising Native Americans as culturally different rather than politically sovereign.77 Carpenter, drawing on Maureen Konkle, ${ }^{78}$ seems to suggest that 'multiculturalism' is a euphemism that undermines or undercuts indigenous heterocephalous sovereignty.79 Carpenter argues that multiculturalism 'functions in part as a colonial effort to forcibly incorporate and thus

\footnotetext{
${ }^{67}$ Nancy Langston, Where Land and Water Meet: A Western Landscape Transformed (Seattle: University of Washington Press, 2003), p. 32.

68 Carpenter, 'Sarah Winnemucca', p. 94.

69 Langston, Land and Water, p. 32.

$7^{\circ}$ Langston, Land and Water, pp. 32-34.

${ }^{71}$ Carpenter, 'Sarah Winnemucca', p. 87.

${ }^{72}$ Langston, Land and Water, pp. 33-34.

73 Langston, Land and Water, p. 67.

74 Langston, Land and Water, p. 63.

75 Carpenter, 'Sarah Winnemucca', pp. 90-91.

${ }^{76}$ Carpenter, 'Sarah Winnemucca', pp. 97-98.

77 Carpenter, 'Sarah Winnemucca', p. 90.

${ }^{78}$ Maureen Konkle, Writing Indian Nations: Native Intellectuals and the Politics of Historiography, 1827-1863 (Chapel Hill: The University of North Carolina Press, 2004), p. 35.

79 Carpenter, 'Sarah Winnemucca', p. 90.
} 
dissolve "difference"". 80 Native Americans must resist this rationality and fight for 'the rights of US citizenship without ceding the independence promised to Natives' in a 'complex dance' for heterocephalous sovereignty. ${ }^{81}$

Winnemucca remains, especially among the Northern Paiutes, a contentious figure, implicated in the white colonial agenda, and the assertion of the Paiutes during the Malheur occupation performs a similar function; it continues the 'complex dance'. It may well be, as it appears here, that 'the disruptive and challenging assertions made by the excluded in equality's name [are] always entangled with the "police" order rather than separate from it'. 82 Furthermore, as Cooper points out, '[r] eading such action as resistance, necessarily located outside centers of power, can obscure and attenuate the power that subordinate forces can and do make use of through their state location'.83

At the same time, it may be this colonial heritage at the heart of the federal government that allows the government to recognise, cooperate with, and defend Native Americans, when it happens to reinforce its own legitimacy, such as by condemning the white conservative militia types that came to Malheur to oppose and question that legitimacy. When the Paiutes maintain that they have good relations with the federal government, they too seem to maintain the colonial hegemony of the federal government in which the Indigenous are subaltern and assimilated to the ‘American' narrative.

If public lands as public things have an important, even formative relationship with democracy, they cannot by their colonial nature directly grant the Burns Paiute Tribe their heterocephalous sovereignty. Understood against the backdrop of the legal and political status of Native Americans in the United States, the struggle for political recognition has troubling implications for the 'democratic' dimension of public lands and perhaps even the pre-neoliberal liberal democracy that birthed them.

Considering the colonial legacy of liberal democracy in the United States, one whose problems are not merely a historical backdrop, but an actively oppressing force in contemporary times, can such democracy be defensible? 84

In other words, if public lands have a political magic that private ones do not, it is one tempered by a lack of democratic mapping. 85 Public lands, as conceived of through the nation-state, are delimited in terms of democracy by the framework of the nationstate; even if public land is mapped democratically, which is certainly not always the case, it is only democratic to the degree that the nation-state itself is. Honig recognises the issue, arguing that the creation and maintenance of public things, including public lands, cannot be limited to the means of the state. Honig argues that while 'criticisms of public things as falsely universal, falsely inclusive, colonial,

\footnotetext{
80 Carpenter, 'Sarah Winnemucca', p. 104.

${ }^{81}$ Carpenter, 'Sarah Winnemucca', p. 104.

82 Cooper, 'Transformative State Publics', p. 318.

83 Cooper, 'Transformative State Publics', p. 318.

84 Compare with the discussion on Hannah Arendt's writings on African Americans and the indigenous peoples of North America in Lukkari's chapter in this collection.
}

85 See Bonnie Honig, 'What Kind of Thing Is Land? Hannah Arendt's Object Relations, or: The Jewish Unconscious of Arendt's Most “Greek” Text', Political Theory 44:3 (2016), pp. 307-336, at p. 318. 
appropriative, and statist have been tremendously important and apt', ${ }^{86}$ we should not see this as:

a reason to oppose public things, as such, or to be reluctant to claim and mobilize their powers now, or to shrink from building new ones. Nor is it a reason to conflate public things with state sovereignty, which today is just one of the mechanisms of their reproduction and can be one of the mechanisms of their betrayal. 87

In addition to the state, there is potential for the support of public things in other political powers, including agency in relation to the state as well as 'alternative sovereignties' constructed by 'with-drawalists' - powers that are not always compatible with each other. ${ }^{88}$ At this level, Honig's theorising can be read as a web of heterocephalous political power. Yet, the idea that 'the state itself is a public thing and worth fighting for' remains explicitly at the core of Honig's theorising. ${ }^{89}$

The complicated discursive performance by the Burns Paiute Tribe brings these threads together. It resists the notion of Native Americans as merely culturally different, and it rejects the notion that the federal government is the rightful owner of the land, while maintaining the possibility of a heterogeneous alliance to keep the land public. 90 To contain democratically vital elements, such an effort need not be done to promote democracy; even when ostensibly aimed at discursively claiming heterocephalous sovereignty and producing conditions for survival, the performance produces not only a discursive alliance in the face of anti-democratic tendencies, but also affirms public lands. Indeed, '[f]ollowing the Paiutes' lead', locals of Harney County assembled to protest the armed occupation. ${ }^{91}$ To draw on Butler, 'through their action, they [brought] the space of appearance into being' .92

For democratic society to exist, the subject capable of democratic knowledge must be constituted in such terms. This is possible through the magic of public things, including public lands, which are, in fact, a prime example of what can be read as the acephalous sovereign even during times of neoliberal assault:

$[\mathrm{P}]$ ublic things stand out as a point worth insisting upon, something that must not be allowed to become part of the morass of despair. Their thingness still enchants, even as their publicness is under pressure. Anyone who has visited a national park can attest to this. 93

\footnotetext{
86 Honig, Public Things, p. 91.

${ }^{87}$ Honig, Public Things, p. 92.

${ }^{88}$ Honig, Public Things, pp. 92-93.

${ }^{89}$ Honig, Public Things, p. 92. Honig still clearly has an affinity for the nation-state that informs the 'publicness' of 'public things'. This is obvious from the examples used in the book.

90 E.g. Kullgren, 'Burns Paiute Tribe’.

${ }^{91}$ Mariya Strauss, 'Keeping Public Lands Public: How Oregon's Rural Communities Rescued the Malheur Wildlife Refuge', New Labor Forum 26:3 (2017), pp. 83-87, at pp. 84-85.

92 Butler, Notes, pp. 88-89.

93 Honig, Public Things, p. 32.
} 
In this sense, the nation-state, regardless of its factually limited heterocephalous sovereignty, continues to shape the democratic imagination. One can be critical of the nation-state, the ways in which it produces domination and is limited in its politically emancipatory potential, and yet one can recognise how the nation-state produces democratic imaginaries in the very moment we live in.

\section{Conclusions}

In the above, I have tried to show the need for a cultural interpretation of sovereignty, one that allows us to understand constituent power in democratic politics. By connecting politics to struggles over cultural meaning, we can use sovereignty as a tool for locating the formation of political subject positions. Mirroring what Minkkinen calls the acephalous, autocephalous, and heterocephalous heads of sovereignty - that is, knowledge, law, and politics - cultural struggles draw on (acephalous) subjectivising knowledge, and perform (autocephalous) social constitution and (heterocephalous) political struggle through discursive performances. These practices challenge and are challenged by relations of power, and the boundedness they delineate is not rigid, but always open to discursive renegotiation.

The subject positions we can analyse through the concept of sovereignty as cultural practice are not necessarily constructed on the concept of democracy itself; it is not always the need for democracy that creates democratic conditions, but our social actions that demand liveable life in the face of precarity. As Giunia Gatta puts it, it is not:

that suffering is constitutive of all political action, but rather that debates around the meaning and the best way to contain our suffering and the suffering of fellow human beings are at the core of contemporary politics, and they constitute often an impetus to engage in political enterprises. 94

The immediate needs and desires of people, for land and sovereignty, are not necessarily thought of in terms of 'democracy', but they can be foundational in producing democratic conditions by constructing democratically subjectivising knowledge out of political alliances and things held in common. They may even do this as they clash with power relations in ways that undermine emancipatory potential.

Social action by itself can be directed in many ways. It can ally a statist conception of public things with Native American sovereignty, or it can be directed towards antistatist, neoliberal, even discriminatory desires. The armed occupiers' claims were exclusionary, ostensibly an attempt at fighting a perceived or experienced precarity, but poised to deepen precarity and anti-democratic politics. The acephalous notion of the sovereign citizen is the root of autocephalous group identity, juxtaposed with the federal government, which is viewed as a hostile competitor on the heterocephalous stage of politics. The historically developed marriage of this type of anti-statism with

94 Giunia Gatta, 'Suffering and the Making of Politics: Perspectives from Jaspers and Camus', Contemporary Political Theory 14:4 (2015), pp. 335-354, at p. 351. Here, like Gatta, I argue for a disruption of 'the binary proposed by Honig between lamentational politics and agonistic humanism'. Gatta, 'Suffering and the Making of Politics', p. 336. 
neoliberalism threatens the acephalous, democratically subjectivising knowledge of public lands.

While the Burns Paiute Tribe at once reject the exclusionary attempts of the occupiers and reaffirm public lands as the lands managed by the federal government, they also assert their claim over the land both as exclusively theirs and as inclusively public. Performatively, the articulation allies a statist conception of democracy with democratic action that does not presuppose a state, and public land as common to both. At the same time, the complexities of context confound any easy answers, exemplified by the colonial history of public lands. This land is the acephalous knowledge that subjectivises a people that is sovereign in the autocephalous sense, and struggling for political recognition in the heterocephalous realm.

We can understand the implications of this conjuncture - and the construction of political identity in general - through the concept of sovereignty as cultural practice. For Eduardo Gill-Pedro, the act of claiming human rights is a political one; to make the claim, we need to see ourselves as potential members of a democratic collectivity. As such, the central task is to bring the process of democracy into being. 95 This process - or discursive struggle over cultural hegemony - is, I argue, rooted in rhetorically constructed subject-positions, which in turn are founded on sovereign knowledge. Here that knowledge is, in the first place, precarity, propelling the inaugural act, and in the second, political alliances that constellate around things held in common. The potential for collective self-recognition as a part of a democratic collectivity appears to already be present in the acknowledging of shared precarity, but as that precarity entails a desire for land and sovereignty, it seems to be derived from (the spectre of) the subjectivising knowledge of public things.

If public lands, like public things in Honig's argument, subjectivise democratic thought, it is the struggle, from precarity, to performatively produce land as public that can challenge the neoliberal threat to democracy. However, because state power produces the subaltern in relation to itself, any effort to ally with the state comes from a compromised starting point and is easily taken as an implicit agreement of how the state operates in regard to land. The democratically subjectivising knowledge of the precariat may be lost. Yet, in the process, it may help create a democratically oriented autocephalous sovereign that can then exercise its democratic principles on the heterocephalous stage. The acephalous sovereign is at once decapitated and capable of producing democratic conditions.

${ }^{95}$ See Gill-Pedro's chapter in this collection. 